\title{
砂利採取船の転 覆海難について
}

\author{
矢 野 健 爾*.寺 本 定 美* \\ On the Capsizing Casualty of Sand Carriers with Grab Buckets \\ Kenji YANO and Sadami TERAMOTO
}

\begin{abstract}
Analizing the Search and Rescue Note, a reguler publication of Japan Maritime Safety Agency, the present writers found out that 13 sand carriers with grab buckets capsized in the past five years since 1969 .

In this paper, we have tried to report the result of the investigation of two sand carriers with grab backets, which capsized near "Mihara Seto" in the Inland Sea of Seto.

These ships, in overloaded condition and insufficient stability, capsized by the partial shifts of sand in their cargo holds.

Based on this analisis, we would like to discuss especially the possible preventation against the capsizing of these ships.
\end{abstract}

\section{1. は じめに}

最近, 数例の転覆海難船舶について, その転覆原因を種々推定し検討する機会を得た。本稿では, これらの転 覆海難船舶のうちから特に, 三原瀬戸付近海域で砂利採取を終え, 同地付近に錨泊中, 樑夜あるいは未明に転覆 した砂利採取船 2 隻を例にとり，種々推定・検討した結果を発表することにした。

言うまでもなく，砂利採取船の操業している海域は，本稿でとりあげた三原瀬戸付近にとどまらず，その操業 規模に差はあるものの，広く全国各海域に分布していると考えられるので，砂利採取船の海難を防止する上で， 少しでも役に立てば幸いである。

御批判を仰ぎたい。

\section{2. 砂利採取船の運航害態とその問題点}

三原瀬戸付近海域は, 海底に堆積した砂利の砂粒が比較的よくそろい良質であるためか, 砂利採取船が多数操 業しており，同海域で砂利採取を許・認可された船舶は，昭和 50 年 6 月 1 日現在で 199 トン型 35 隻，499 トン 型 15 隻を含め, 総計約 55 隻に達している。この海域で採取された砂利は，航海時間に換算して約 $3 \sim 4$ 時間の 距離にある広島・吳・水島の諸港に主として運搬・陸揚げされ, 海岸の埋立, 道路の建設, 建築工事等に使用さ れている。しかしながら，最近実施されている公共事業の抑制や不況の浸透のためか，砂利の需要が減退し，こ のため砂利採取業者間に過当競争が始まり，その価格泜低落し，更に燃料費の高騰も加わって，必然的により多 くの砂利を採取運搬しなければならなくなった。この結果, 砂利採取船の多くは, 写真1に示すように, 砂利の 積み過ぎのため上甲板を波が洗う状態で航走しているのが現状である。

一般に, 砂利採取船には 1 2 基の砂利採取用クレーン(グラブバケット容量 $1 \sim 1.5 \mathrm{~m}^{3}$ )を装備しており，こ れを使用して海底から砂利を直接採取し船倉に積載している。同海域の 499 トン型は, 満船になるまでの所要時 間は 3 4 時間であり，満船（すなわち砂利採取終了）時機は本船の舴側における水線位置を基準にとり，適宜経

* 正会員 海上保安大学校 (点市若葉町 1-1) 


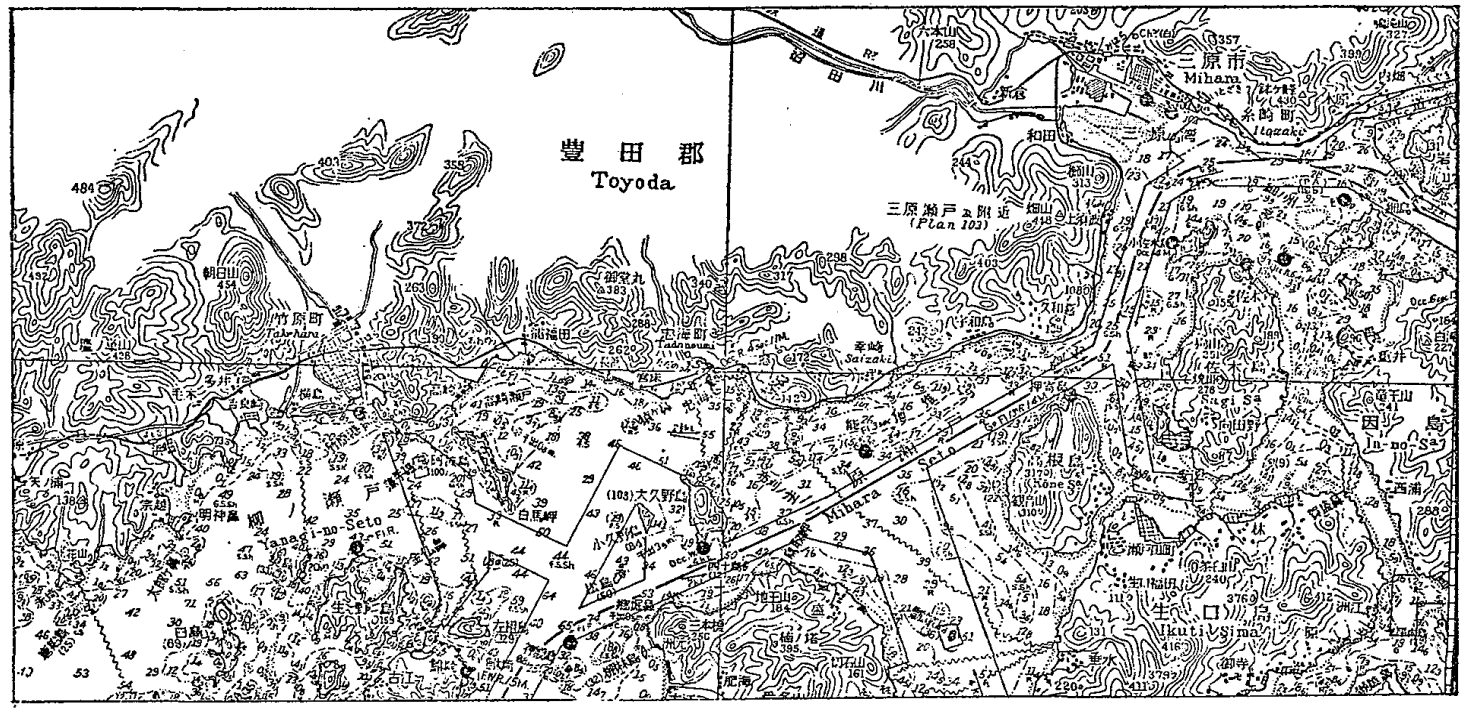

図 1 三原瀬戸および付近（水路図誌複製「海上保安庁承認第 52061 号」）

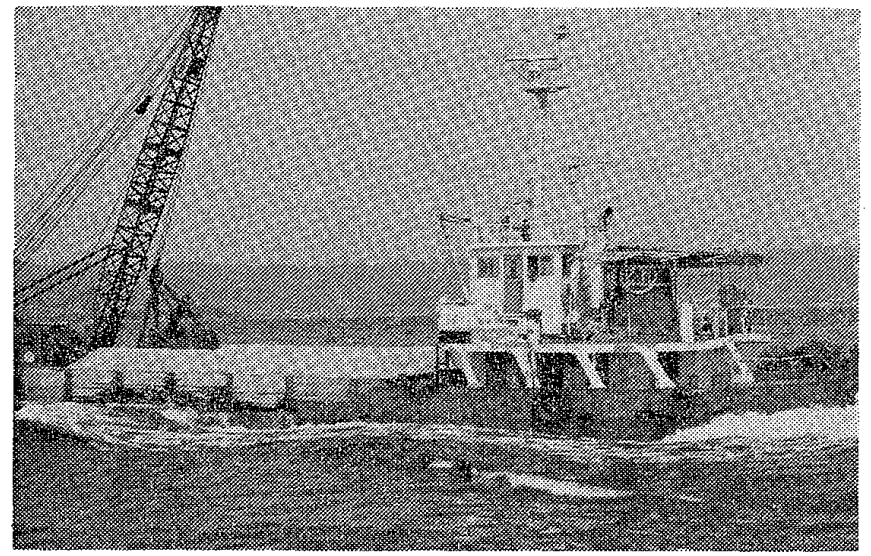

写真 1

験的に判断している。船倉に砂利を積載し始めると， グラブバケットにより砂利と共に採取された海水が 分離し船倉底に畽留し始めるので，この海水を船外 に排出する水切り作業が始まる。この作業は，砂利 の積載量の増加をはかる上からも，また砂利の流動 化を防止し，適正な復原力を保持する上からも，欠 かすことのできない重要な作業である。本作業は， 調査によると通常下記のような 2 段階に分けて行わ れている。第 1 段階は，以わゆる急速排水作業であ る。これは，砂利採取作業の進行に伴って，砂利か ら分離して倉内に多量に滞留し始めた海水を船外に 排出するために行われるもので，砂利採取開始時か ら採取終了後の $2 \sim 3$ 時間までを指す。この排水作

業の終了した時点では, 満船時よりも船体は約 $20 \sim 30 \mathrm{~cm}$ 浮上するを言われている。

第 2 段階は，第 1 段階の作業終了後から砂利の陸揚げまでに行われる，以わゆる通常の排水作業である。砂利 に付着している海水は，時閭経過と共に，徐々に分離・滲出し，穦荷の下層から船倉底にかけて滞留してゆくの で，この海水を排除するため排水ポンプを連続あるいは断続的に運転する。この作業の適・不適がビルジ溜りお よび船倉底の海水の増加とも絡んで，砂利の流動性に大きな影響を与えるので，採取後錨泊する場合のように， 掦荷まで長時間経過するような場合には特に注意が必要となる。

採取された砂利は，満船状態では船倉からはみ出し，倉口上に山のように盛り上げた状態で積載されており， この結果乾舷はほとんど“0”となり，既述のよらに上甲板を波で洗いながら航走している船を多数見受ける。 このため，重心位置は大巾に上昇し，滞留した海水が砂利を流動化していることもあいまって，船体はわずかの 外力の影響によっても極めて容易に傾斜し得る状態になっている。

一方，ジブを立てて，その仰角を加減することにより，クレーン全体の重心位置すなわち水平面内のバランス を調整しておき，船の傾斜に応じでブを旋回させその移動モーメントにより横傾斜を修正することも行われて いる。このような操作を行って傾斜を修正しながら航走している状況を写真 2 に示す。このような船は，潮流の 速い瀬戸を航過する時や，他船の航走波の影響を受ける時，あるいは自船が転舵した時など，復原性が劣化して いるため簡単に傾斜し，しかも一歩対策を誤れば転覆する恐れがあるので特に注意が必要である。

既述のように，砂利採取作業は 3〜4 時間で終了するが，陸揚地の荷役時刻の調整のためか採取現場付近の陸 岸寄りに適宜錨泊し，翌日早朝抜錯し陸掦地へ向う砂利採取船も多い。これらの船は，深夜当直を立てず就浸し 
ているためか，いわゆる第 2 段階の水切り作業が有 効に行われす，船倉底やビルジ溜りには砂利から徐 々に分離した海水がたまり，潮流による船体の振れ 回り運動や風波の影響が加わって砂利の層が崩れ， 次第に船体が傾斜してゅくことに気付か始場合が多 w。

本稿でとりあげた 2 例の転覆海難船は，このよう にして錯泊中次第に傾斜角が大きくなりついに転覆 するに至ったものである。

\section{N丸と $\mathrm{S}$ 丸の転覆経過概要}

三原瀬戸付近海域で錨泊中転覆したN丸と S丸の 転覆当時の記録および引揚げ後の船体調査等の結果 をもとに転覆原因の検討を行った。表 1 は丸と $\mathrm{S}$ 丸の主要寸法であり，参考のため 500 総トン型貨物 船（中小型鋼船標準基本設計：昭和 42 年 6 月, 日本 中小型造船工業会）の主要寸法を併記した。また, 写真 3 には，船体引揚げ後造船所に回航したS丸を 示した。なお，要救助海難統訫(1)によれば，昭和 44 $\sim 48$ 年の 5 年間に 13 隻の砂利採取船が, 過載, 積 付不良乞の他の理由で転覆しており，これらの転覆 時機注砂利採取直後や錯泊中あるい注回頭中に発生 している。

N丸の転覆当時の概要は下記のとおりである。昭 和 49 年 3 月 10 日，竹原市大久野島沖海面で海砂約 $700 \mathrm{~m}^{3}$ を採取した後, 同日午後 0 時頃，同市忠の 海港沖に錨泊した。同日午後 10 時頃乗組員が就葠 するに際し，船体が右に約 $3^{\circ}$ 傾斜しているのを発 見し，ガットクレーンを左舷側に移動して傾斜を修 正し，同時に船倉に滞留していた海水を船外に排出 した後全員（5名）が就葠した。翌 11 日午前 3 時 頃, 船体が左舴に約 $15^{\circ}$ 傾斜していることに船長が 気付き，直ちに全員を起こし，ガットクレーンを動 かして傾斜を修正しよらとしたが，船体は復原せず そのまま左舴側から海水が浸入転覆した。当時の天

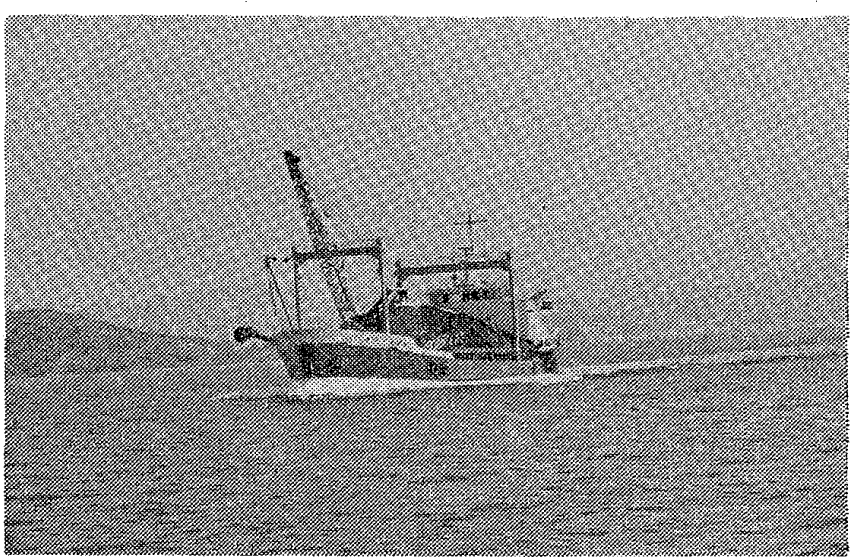

写真 2

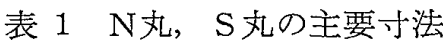

\begin{tabular}{r|r|r|r}
\hline & $\mathrm{N}$ 丸 & $\mathrm{S}$ 丸 & 貨物船 \\
\hline $\mathrm{L}(\mathrm{m})$ & 49.50 & 49.50 & 49.00 \\
\hline $\mathrm{B}(\mathrm{m})$ & 9.30 & 9.00 & 9.00 \\
\hline $\mathrm{D}(\mathrm{m})$ & 4.60 & 4.50 & 4.40 \\
\hline $\mathrm{d}(\mathrm{m})$ & 4.30 & 4.05 & 4.00 \\
\hline G.T. (t) & 約 499 & 約 499 & 約 500 \\
\hline
\end{tabular}

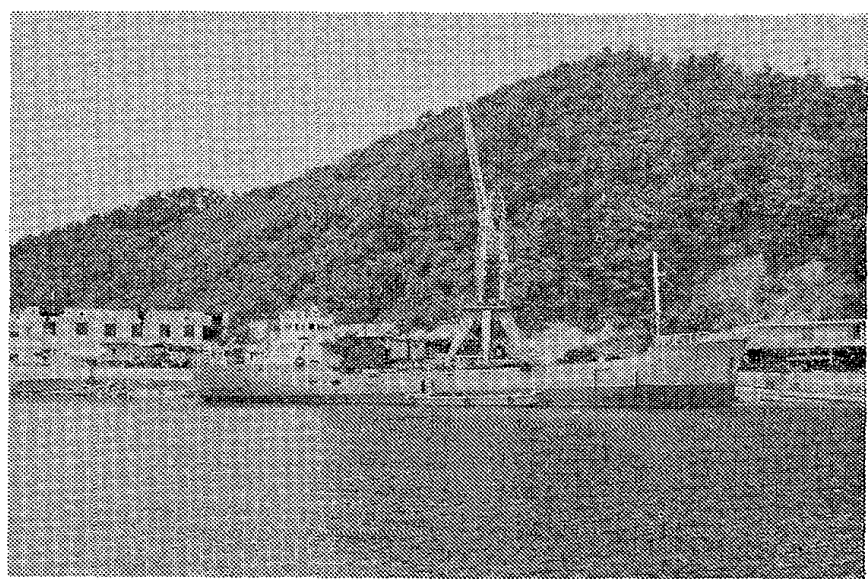

写真 3 候は，薄昙り，北風 $2 \sim 3 \mathrm{~m}$ ，視界は良好で海上は平穏であった（なお，乗組員は全員船外に脱出しことなきを 得た)。

一方, $S$ 丸転覆当時の概要は次のと扝りである。昭和 50 年 4 月 5 日午前 4 時 40 汾頃, 三原市幸崎沖で転覆し 船首部船底が水面上に露出しているのを，現場付近海域を東航していた砂利採取船 $\mathrm{D} 丸 か ゙$ 発見した。その後の調 查の結果， $\mathrm{S}$ 丸は 4 月 4 日正午頃水島港を空船で出港し，同日午後 4 時頃転覆現場付近海面に到着，右舷錨を投 錨し砂利採取を開始した。同日午後 7 時 30 分頃砂利採取を終え，引続き同地に錯泊しており，翌 5 日午前 2 時 頃抜錨し水島港に向う予定であったことが判明した。なお，同錨地付近の当日の海上模様は平穏であり，潮流は 最大約 2.2 ノットと推定される。転覆時刻は船内時計の停止状況から判断して，4 日午後 11 時頃と推定され， 乗組員は 6 名中 4 名は遺体となって船内で発見されたが，残る 2 名は行方不明となった。

なお， $\mathrm{S} 丸 は ，$ 沿海の航行区域を有していたが，その後昭和 50 年 2 月平水区域に変更していた。写真 4 は, 


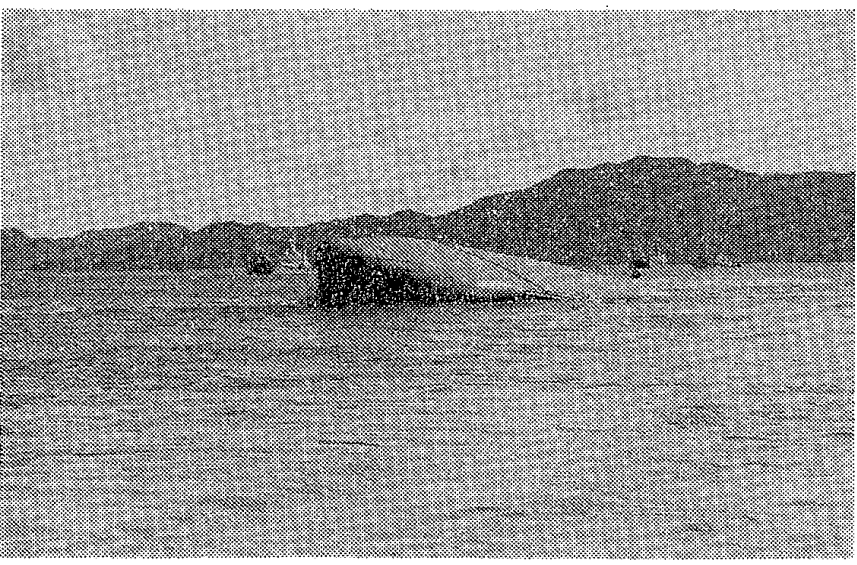

写頁 4

表 2 砂利採取前後の喫水（推定）

\begin{tabular}{cc|cc|c|c}
\hline \hline 船 & 名 & 砂利採取 & 船首喫水 & $\begin{array}{c}\text { 船尾喫水 } \\
(\mathrm{m})\end{array}$ \\
\hline \multirow{2}{*}{$\mathrm{N}$} & \multirow{2}{*}{\begin{tabular}{c} 
丸 \\
\cline { 3 - 5 }
\end{tabular}} & 直 & 前 & 0.80 & 3.20 \\
\cline { 3 - 5 } & & 直 & 後 & 4.40 & 4.60 \\
\hline \multirow{2}{*}{$\mathrm{S}$} & 丸 & 直 & 前 & 0.60 & 3.20 \\
\cline { 3 - 5 } & & 直 & 後 & 4.20 & 5.20 \\
\hline
\end{tabular}

ごき推定した砂利採取前後に㧍ける喫水である。

調査によると急速排水の所要時間は約 2 3 時間であり，この間に船体は $20 \sim 30 \mathrm{~cm}$ 浮上することが判明した。

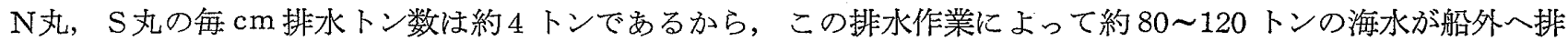
除されたことになる。写真 5 は，満船に近くなった 499 トン型砂利採取船の急速排水中の状況を示したものであ る。なお，この写真にある 3 個所の排水口ほ船内側より蓋がなされている。

これらの資料に基づいて転覆当時の排水量および砂利採取量を計算した結果，排水量は $\mathrm{N}$ 丸約 1465 トン， $\mathrm{S}$ 丸約 1535 トン, 砂利採取量は， $\mathrm{N}$ 約 $700 \mathrm{~m}^{3}, \mathrm{~S}$ 約 $800 \mathrm{~m}^{3}$ であった。なお, 砂利の採取量については, 積
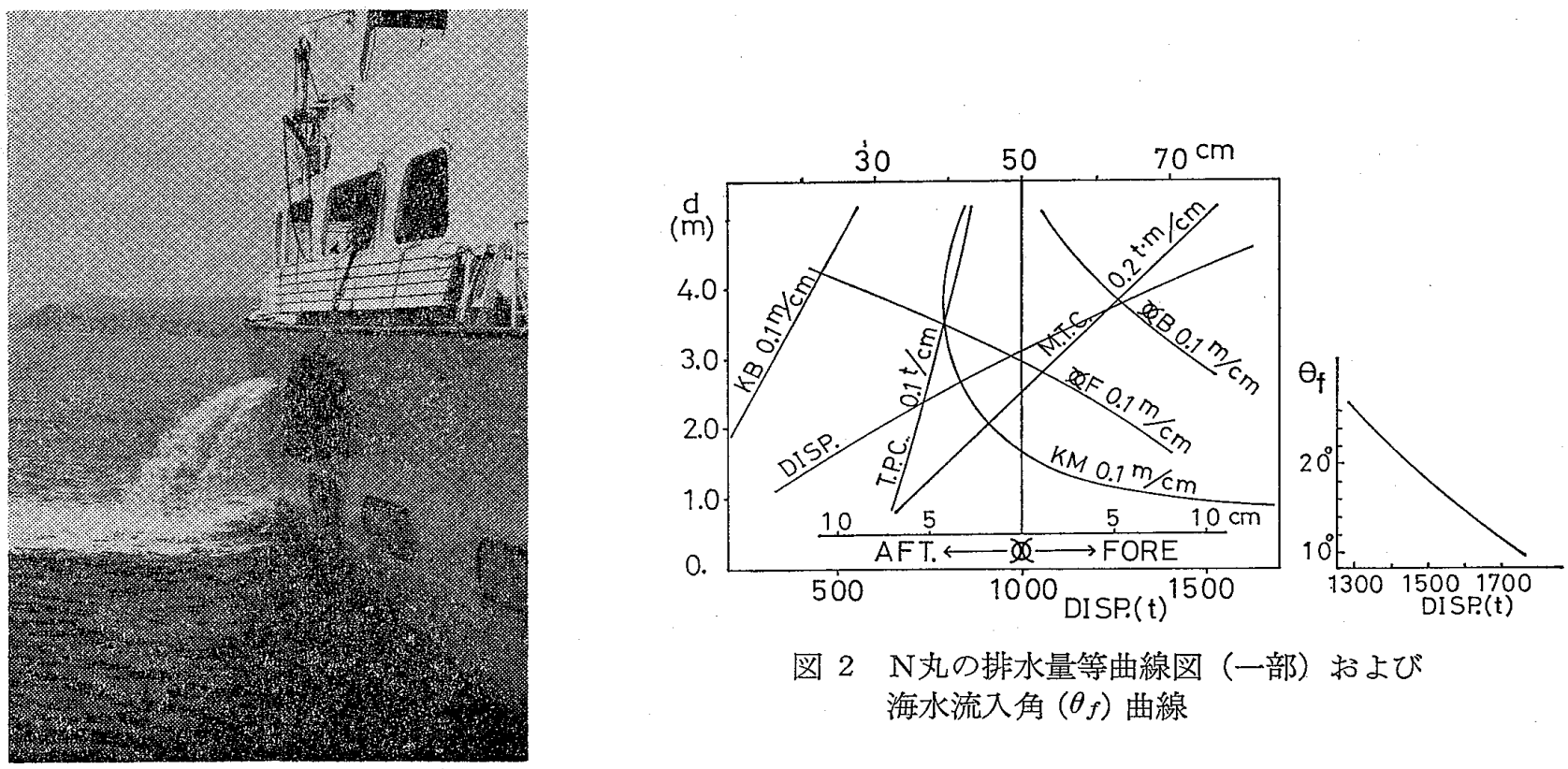

図 2 N丸の排水量等曲線図（一部）および 海水流入角 $\left(\theta_{f}\right)$ 曲線 
付状況の見取図，船倉容積，船倉に残っていた砂利の比重計測などからその妥当性を確認した。また，S丸は満 船時その上甲板航端を海水が洗っていたものと推定される。参考までに，N丸の排水量等曲線図（一部）および 海水流入角曲線索図 2 亿示す。

4.2 転覆当時の重心高さ $(K G), G_{0} M$ および自由水の影響について

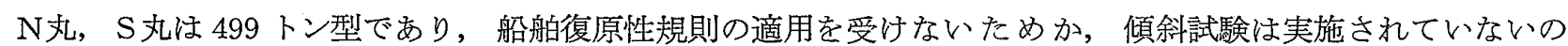
で，その重心高さを推定することは困難であるが，同型又は類似の小型鋼船 5 隻の傾斜試験成績書・重量重心計 算晝等を入手し，これらをもとに砂利採取用クレーン・積荷等の影響を修正して概略の重心高さを求めることに した。

表 3 類 似型船 の要目等

\begin{tabular}{|c|c|c|c|c|c|c|}
\hline 船 & 名 & 丸 & $丸$ & 丸 & 丸 & 丸 \\
\hline 船 & 種 & 砂＼cjkstart利 & 貨＼cjkstart物 & 貨物 & タンカー & 物 \\
\hline \multirow[t]{2}{*}{ 総 } & 屯 数 & $481.16^{t}$ & $484.00^{t}$ & $499 \quad t$ 型 & $499 \quad t$ 型 & $500 \quad t$ 型 \\
\hline & $\mathrm{L} \quad(\mathrm{m})$ & 50.00 & 49.50 & 49.50 & 52.00 & 49.00 \\
\hline \multicolumn{2}{|c|}{$B \quad(m)$} & 11.00 & 9.00 & 9.00 & 9.00 & 9.00 \\
\hline \multicolumn{2}{|r|}{$\mathrm{D} \quad(\mathrm{m})$} & 4.70 & 4.50 & 4.50 & 4.50 & 4.40 \\
\hline \multirow{3}{*}{ 軽 } & $W \quad(t)$ & 600.48 & 425.76 & 364.54 & 394.19 & 361.00 \\
\hline & $\mathrm{d} \quad(\mathrm{m})$ & 1.706 & 1.541 & 1.300 & 1.392 & 1.320 \\
\hline & $\mathrm{KB}(\mathrm{m})$ & 0.940 & 0.840 & 0.680 & 0.760 & 0.690 \\
\hline \multirow{2}{*}{$\begin{array}{l}\text { 荷 } \\
\text { 状 }\end{array}$} & $\mathrm{KG}(\mathrm{m})$ & 4.557 & 4.174 & 3.600 & 3.700 & 3.550 \\
\hline & $\mathrm{GM}(\mathrm{m})$ & 2.163 & 0.968 & 1.970 & 1.620 & 2.030 \\
\hline \multirow[t]{2}{*}{ 態 } & $\mathrm{KB} / \mathrm{d}$ & 0.551 & 0.545 & 0.523 & 0.546 & 0.523 \\
\hline & $\mathrm{KG} / \mathrm{D}$ & 0.970 & 0.928 & 0.800 & 0.822 & 0.807 \\
\hline \multirow{7}{*}{$\begin{array}{l}\text { 茜 } \\
\text { 載 } \\
\text { 盖 } \\
\text { 港 } \\
\text { 㞺 }\end{array}$} & $W \quad(t)$ & 1921.71 & 1508.00 & 1425.00 & 1508.00 & 1335.00 \\
\hline & $\mathrm{d} \quad(\mathrm{m})$ & 4.523 & 4.405 & 4.130 & 4.300 & 4.010 \\
\hline & $\mathrm{KB}(\mathrm{m})$ & 2.436 & 2.390 & 2.250 & 2.230 & 2.150 \\
\hline & $\mathrm{KG}(\mathrm{m})$ & 3.789 & 3.573 & 3.170 & 2.900 & 3.200 \\
\hline & $\mathrm{GM}(\mathrm{m})$ & 0.961 & 0.407 & 0.620 & 0.960 & 0.680 \\
\hline & $\mathrm{KB} / \mathrm{d}$ & 0.539 & 0.543 & 0.545 & 0.519 & 0.536 \\
\hline & $\mathrm{KG} / \mathrm{D}$ & 0.806 & 0.794 & 0.704 & 0.644 & 0.727 \\
\hline \multirow{7}{*}{$\begin{array}{l}\text { 空 } \\
\text { 艙 } \\
\text { 敢 } \\
\text { 港 } \\
\text { 態 }\end{array}$} & W $\quad(\mathrm{t})$ & - & 599.21 & 612.20 & 527.84 & 707.80 \\
\hline & $\mathrm{d} \quad(\mathrm{m})$ & $\longrightarrow$ & 2.042 & 1.970 & 1.770 & 2.310 \\
\hline & $\mathrm{KB}(\mathrm{m})$ & - & 1.110 & 1.050 & 0.960 & 1.240 \\
\hline & $\mathrm{KG}(\mathrm{m})$ & $\longrightarrow$ & 3.662 & 2.870 & 3.610 & 2.450 \\
\hline & $\mathrm{GM}(\mathrm{m})$ & —. & 0.756 & 1.690 & 1.010 & 1.630 \\
\hline & $\mathrm{KB} / \mathrm{d}$ & - & 0.544 & 0.533 & 0.542 & 0.537 \\
\hline & $\mathrm{KG} / \mathrm{D}$ & - & 0.813 & 0.638 & 0.802 & 0.557 \\
\hline
\end{tabular}


表 3 は，入手した 5 隻の主要寸法および各種状態における排水量・重心高さ等を示してある。S丸は乗組員が 全員死亡又は行方不明になっていたので，重心位置の推定は上記の方法のみによった。一方，N丸についてはこ のほか，クレーン操作による横傾斜角の修正方法が判明したので，この資料をもとに $G_{0} M=w ・ l / W \cdot \tan \theta$ の関 係を用いて $K G_{0}$ を推定し，上記から求めた結果と比較してその妥当性を検討した。

転覆原因を調査するため, 船体引揚後に排水ポンプ，バルブの開閉状況，配管系統，配電盤，船外吐出口等の 調查を行った。S丸は船倉の前後部にそれぞれ隣接した長さ各々 $6 \mathrm{~m}, 4.5 \mathrm{~m}$ で幅は船幅とほぼ同じ程度の空倉 をもっており，その空倉底には砂利と共に採取された海水を排除するためのビルジ溜りが設置されている。

砂利採取中は，砂利と共に大量に採取される海水のため急速排水しても排水が追い付かず，海水がビルジ溜り からあふれ出し, 空倉底全面にわたって海水が充満している。特に, 後部空倉は通常の排水の時でも, ビルジ溜 りの形状からビルジ溜りのみでなく, 空倉底全面に海水がたをるよらになっており, 現場調查を行った時にも床 上 $10 \sim 20 \mathrm{~cm}$ のビルジが滞溜していた。

この自由水による見掛けの重心の上昇は $0.17 \mathrm{~m}$ に相当する計算になる。

写真 6 は, $\mathrm{S} 丸$ 前部空倉内に設置されているビルジ溜りとビルジパイプの様子を示す。

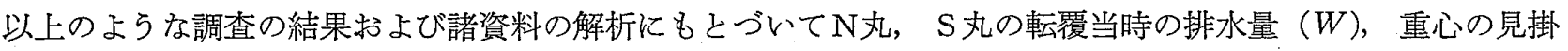
けの高さ $\left(K G_{0}\right)$ ，見掛け $G M\left(G_{0} M\right)$ 等を推定した結果を表 4 に示した。

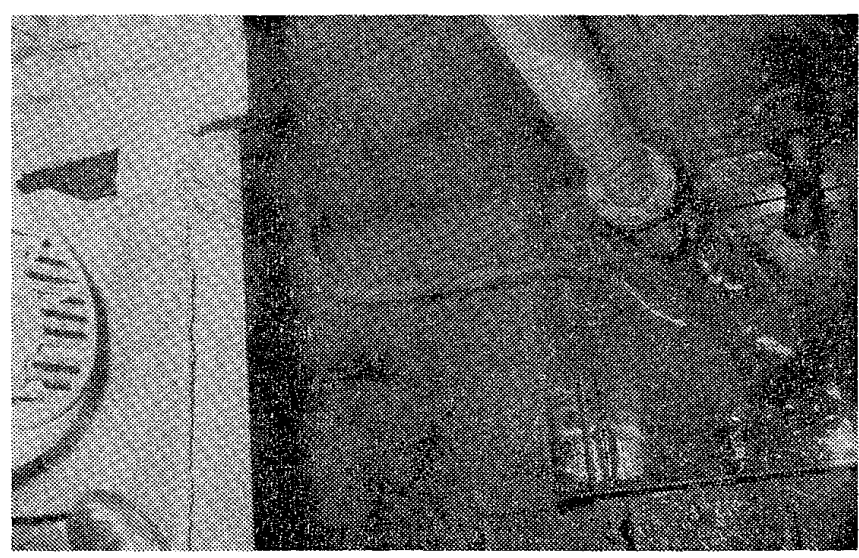

写真 6

表 $4 \mathrm{~W}, \mathrm{KG}_{0}, \mathrm{G}_{0} \mathrm{M}$ 等

\begin{tabular}{c|c|c|c|c|c}
\hline \hline 船名 & $W(\mathrm{t})$ & $\mathrm{KG}_{0}(\mathrm{~m})$ & $\mathrm{G}_{0} \mathrm{M}(\mathrm{m})$ & $\mathrm{KG}_{0} / \mathrm{D}$ & $\mathrm{G}_{0} \mathrm{M} / \mathrm{B}$ \\
\hline $\mathrm{N丸}$ & 約 1465 & 3.65 & 0.35 & 0.793 & 0.038 \\
\hline $\mathrm{S丸}$ & 約 1535 & 3.64 & 0.36 & 0.809 & 0.040 \\
\hline
\end{tabular}

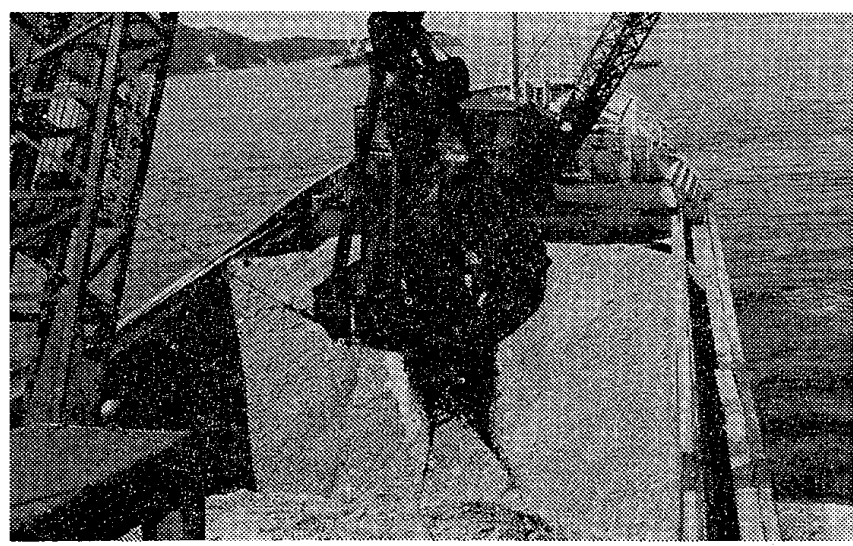

写真 7

\section{3 砂利の荷崩れによる船体傾斜と復原力} 砂利採取船は，砂利採取用クレーンを 1 基又は 2 基装備しているが，砂利を積載する場合には，クレ ーン 1 基装備の船の場合には通常採取した砂利を船 倉中央に盛り上げるように積載し，砂利が倉口頂部 をこえるよらになると船倉の前・後部方向に砂利の 山を移動させ，平らにならす方法をとっている。ク レーン 2 基を装備している船では, 船首・尾寄りの 船倉にそれぞれ盛り上げて積載し，倉口頂部をこえ るようになると盛り上がった 2 つ山を中央部によ せて，全体が平らになるように積載している。写真 7 はクレーン 2 基装備している船の砂利積載中の様 子を示している。

このように，砂利の表面を平らにならすような作 業を行っても, 左右両舴の上甲板下肩部は砂利の静 止角のため空積となりやすい。その上，コーミング 頂部付近まで砂利を積載した状態では，平らになら す作業を行っても空積部分はなかなか砂利で埋める ことができない。なお文献(2)によると，積倚の種類

表 5 積荷の種類と静止角

\begin{tabular}{|c|c|}
\hline 積 荷 の種 類 & 静止 \\
\hline 穀 物 （乾燥時） & $30^{\circ} \sim 31^{\circ}$ \\
\hline 穀 物 （普通時） & $35^{\circ} \sim 37^{\circ}$ \\
\hline 石 & $30^{\circ} \sim 50^{\circ}$ \\
\hline 土砂 - 砂 利 & $30^{\circ} \sim 45^{\circ}$ \\
\hline 鉣 & $30^{\circ} \sim 50^{\circ}$ \\
\hline セ メ ン & $45^{\circ} \sim 50^{\circ}$ \\
\hline
\end{tabular}


別の静止角は表 5 に示すとおりである。

いま，横傾斜角と砂利の崩壊量との関係を求めるため，“上甲板下肩部付近の静止角を保っていた砂利の層が 崩れて空積部分に移動し，このあとを埋めるためハッチコーミング内の砂利の層が宿没した”ものであると仮定 し，ハッチコーミング内の砂利の層の陷没の形状に応じて，下記の 4 種のモデルを想定した。

(A) 砂利層の陌没断面形状が，コーミング幅 $2 b$, 深さ $a$ の長方形である場合。(図 3 CASE (A))

（B）砂利層の陮没断面形状が，コーミング半幅 $b$ ，深さ $a$ の長方形である場合。（図 3 CASE (B))

(C) 砂利層の陥没断面形状が，コーミング幅 $2 b$ ，深さ $a$ の直角三角形である場合。（図 3 CASE (C))

（D） 砂利層の陮没断面形状が，コーミング半幅 $b$, 深さ $a$ の直角三角形である場合。（図 3 CASE (D))

これら 4 種のモデルに応じて，それぞれ砂利の崩壊部分の重心の下降距離 $H$, 横方向の移動モーメント $m_{h}$ ， 上下方向の移動モーメント $m_{v}$ の計算式を作り表 6 に示した。この場合，崩壊した砂利層の舴側での高さ $x$ は， $x \leqq b^{\prime} \tan \alpha$ とする。
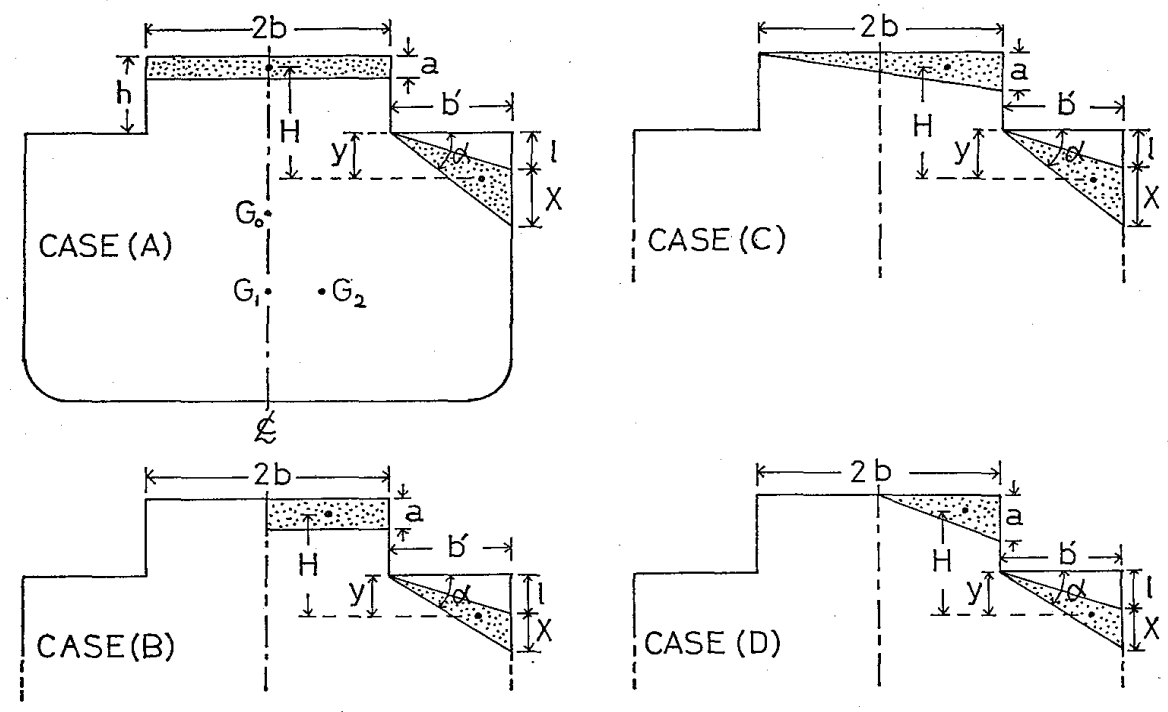

図 3 砂利移動のモデル

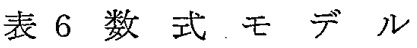

\begin{tabular}{c|c|c|c|c}
\hline \hline & $(\mathrm{A})$ & $(\mathrm{B})$ & $(\mathrm{C})$ & (D) \\
\hline$x$ & $4 a \frac{b}{b^{\prime}}$ & $2 a \frac{b}{b^{\prime}}$ & $2 a-\frac{b}{b^{\prime}}$ & $a \frac{b}{b^{\prime}}$ \\
\hline$y$ & $\frac{2}{3}\left(b^{\prime} \tan \alpha-2 a \frac{b}{b^{\prime}}\right)$ & $\frac{2}{3}\left(b^{\prime} \tan \alpha-a \frac{b}{b^{\prime}}\right)$ & $\frac{2}{3}\left(b^{\prime} \tan \alpha-a \frac{b}{b^{\prime}}\right)$ & $\frac{2}{3}\left(b^{\prime} \tan \alpha-\frac{a}{2} \cdot \frac{b}{b^{\prime}}\right)$ \\
\hline $\mathrm{H}$ & $h+\frac{2}{3}\left\{b^{\prime} \tan \alpha\right.$ & $h+\frac{2}{3}\left\{b^{\prime} \tan \alpha\right.$ & $h+\frac{2}{3}\left\{b^{\prime} \tan \alpha\right.$ & $h+\frac{2}{3}\left\{b^{\prime} \tan \alpha\right.$ \\
\hline$m_{h}$ & $2 \gamma_{s} a b^{2} L\left(1+\frac{2}{3} \cdot \frac{b^{\prime}}{b^{\prime}}\right)$ & $\frac{1}{2} \gamma_{s} a b^{2} L\left(1+\frac{4}{3} \cdot \frac{b^{\prime}}{b}\right)$ & $\frac{2}{3} \gamma_{s} a b^{2} L\left(1+\frac{b^{\prime}}{b}\right)$ & $\frac{1}{3} \gamma_{s} a b^{2} L\left(\frac{1}{2}+\frac{b^{\prime}}{b}\right)$ \\
\hline$m_{v}$ & $2 \gamma_{s} a b L\left[h+\frac{2}{3}\left\{b^{\prime} \tan \alpha\right.\right.$ & $\gamma_{s} a b L\left[h+\frac{2}{3}\left\{b^{\prime} \tan \alpha\right.\right.$ & $\gamma_{s} a b L\left[h+\frac{2}{3}\left\{b^{\prime} \tan \alpha\right.\right.$ & $\frac{1}{2} \gamma_{s} a b L\left[h+\frac{2}{3}\left\{b^{\prime} \tan \alpha\right.\right.$ \\
& $\left.\left.-\left(\frac{3}{4}+2 \frac{b}{b^{\prime}}\right) a\right\}\right]$ & $\left.\left.-\left(\frac{3}{4}+\frac{b}{b^{\prime}}\right) a\right\}\right]$ & $\left.\left.-\left(\frac{1}{2}+\frac{b}{b^{\prime}}\right) a\right\}\right]$ & $\left.\left.-\frac{1}{2}\left(1+\frac{b}{b^{\prime}}\right) a\right\}\right]$ \\
\hline
\end{tabular}

$L:$ コーミング長さ, $\alpha$ : 静止角, $\gamma_{s}$ : 砂利比重 
表 7 数值計算結果 (S丸)

\begin{tabular}{lc|c|c|c|c}
\hline \hline & & $(\mathrm{A})$ & $(\mathrm{B})$ & $(\mathrm{C})$ & (D) \\
\hline$x$ & $(\mathrm{~m})$ & $8 a$ & $4 a$ & $4 a$ & $2 a$ \\
\hline$y$ & $(\mathrm{~m})$ & $0.70-2.67 a$ & $0.70-1.33 a$ & $0.70-1.33 a$ & $0.70-0.67 a$ \\
\hline$H$ & $(\mathrm{~m})$ & $1.80-3.17 a$ & $1.80-1.83 a$ & $1.80-1.67 a$ & $1.80-a$ \\
\hline$m_{h}$ & $(\mathrm{t} \cdot \mathrm{m})$ & $671 a$ & $210 a$ & $252 a$ & $84 a$ \\
\hline$m_{v}$ & $(\mathrm{t} \cdot \mathrm{m})$ & $(302-531 a) a$ & $(151-154 a) a$ & $(151-140 a) a$ & $(75-42 a) a$ \\
\hline$a$ の範围 & $(\mathrm{m})$ & $<0.13$ & $<0.26$ & $<0.26$ & $<0.53$ \\
\hline
\end{tabular}

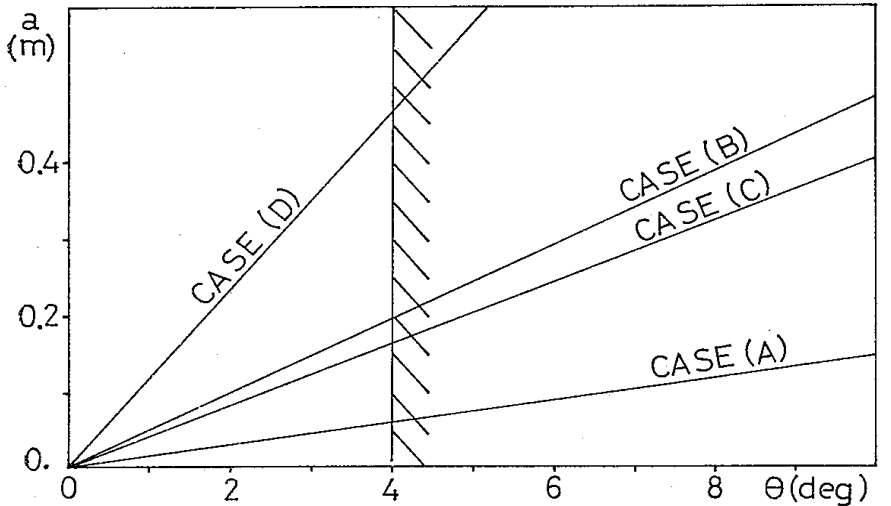

図 $4 \quad a-\theta$ 曲線 ( $\mathrm{S丸}$ )

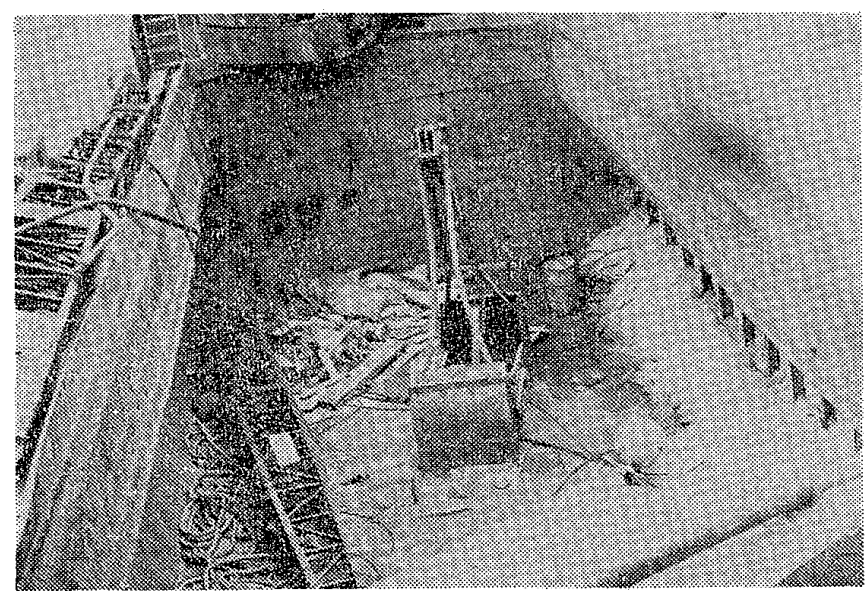

写真 8

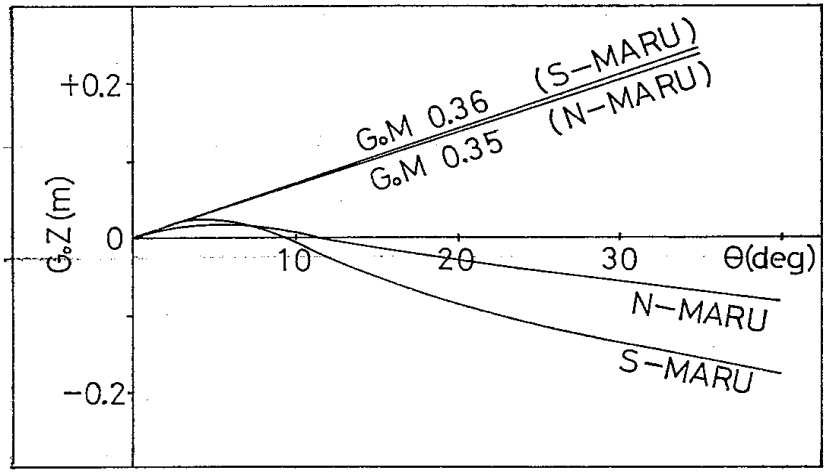

図 5 転覆当時の $\mathrm{G}_{0} \mathrm{Z}$ 曲線（推定）
表 7 おび図 4 は，表 6 をもとにS丸について計 算した結果を示してある。

ここで, 重心の下降距離 $G_{0} G_{1}$, 横移動距離 $G_{1} G_{2}$ とおけば

$$
G_{0} G_{1}=m_{v} / W, \quad G_{1} G_{2}=m_{n} / W
$$

であるから, 船体横傾斜角 $\theta$ は

$$
\tan \theta=m_{h} / W \cdot G_{0} M+m_{v}
$$

で与えられる。ただし， S丸は $b^{\prime} / b=0.50, h=1.1$ $\mathrm{m}$ (さし板部分を含む) $, L=21.5 \mathrm{~m}, b=3.0 \mathrm{~m}$ であ 万。

写真 8 は船体引揚当時の $\mathrm{S} 丸 の$ 船倉内部の状況を 示したものである。当時, 船倉内に残っていた砂利 を採取し，種々加湿して $\alpha$ および $\gamma s$ を計測した結 果, その平均值しして $\alpha=35^{\circ}, \gamma_{s}=1.30$ を得た。

図 5 の $G_{0} Z$ 曲線は, 既述のような種々の条件下 で推定した結果得られたものである。過載のため乾

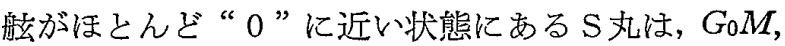
$G_{0} Z_{\max }$, 復原性範囲等㵔しく小さくなっており, $G_{0} Z \fallingdotseq G_{0} M \cdot \theta$ の成立する範囲も大幅に減少 $\left(4^{\circ}\right.$ 程 度）している。

砂利の層が，第 3 図 CASE (A)〜 (D) に示す各 モデルのように宿没した場合，aの值がそれぞれ $0.06 \mathrm{~m}, 0.19 \mathrm{~m}, 0.16 \mathrm{~m}, 0.47 \mathrm{~m}$ 程度になると船体 傾斜角は上述の $4^{\circ}$ 程度になる（第 4 図）。しかしこ の状態では，上甲板下肩部にはまだ空積が残ってい るので，この空積部分に问けさらに砂利の移動が継 続して起こり，その上傾斜舴側船倉底部には水切り 不良にもとづく海水が滞留するので，遂に復原モー メントを上回るようになり転賈するに至る。

以上曰ように考察してくると, 復原性が著しく覀 化しているN丸，S丸の転覆の有力原因として，上 甲板下肩部に生じた砂利の空積部分の存在がクロー ズアップされてくる。

このほか，両船のように復原性が劣化した状態で 
鈿泊している場合の砂利移動の原因として，砂利層内部に生じた空洞部分の存在や，鈚泊中の船体振れ回り運動 にもとづく横傾斜が考えられるが，今後の研究課題である。

\section{5.むす び}

転覆当時，両船はともに砂利を過載しており，その上砂利から分離・滲出してきた海水の影響吕加わり $G_{0} M$, $G_{0} Z_{\max }$ が著しく減少し，またその復原性範囲も減少して海水流入角（当時 $\mathrm{N} 丸$ は約 $19^{\circ}, \mathrm{S} 丸$ 丸約 $16^{\circ}$ 程度） 以下になっていたものと推定される。

$\mathrm{S} 丸 に つ い て は ， 50$ 年 2 月に航行区域を沿海から平水に資格変更したため, 満載契水線規則の適用が除外され たことを考台合わせると，転覆当時の乾舴はほとんぞ“0”に近い状態になっていたものと推定される。

その上，染夜立直をしていなかったため，潮流による船体の振れ回りや他船の航走波等による船体の動摇の影 響で，砂利和よび滞留している海水が徐々に移動し始め，次第に船体が傾斜してゆき，誰れも気付くことなく遂 に転覆したのではなかららか。

一方，N丸の場合は，就寝前に船体が右舴に傾斜していたので，クレーンを操作して傾斜を修正し，同時に船 倉底やビルジ溜りにたまっていた海水を船外に排水した後全員就寝している。しかし，船倉内の砂利をならして 傾斜を修正したわけではないから，傾斜の原因となっていた海水を含んだ砂利層は依然不安定な状態で残ってい たと考えられる。翌日末明，今度注左舴に約 $15^{\circ}$ 傾斜していることに船長が気付き，クレーンを操作して傾斜を 修正しょうとしたが， $G_{0} Z$ はほとんぜ“0 又は賲”になっていたものと推定されるので，かえって傾斜が増大 し遂に転覆したものであるう。

以上のように考えてくると，その転覆の原因は，より根本的には，造船所側が設計に際し想定した砂利の積付 状態と，運航者側の積付の実情が大きく食い違っていることにあると考えられる。砂利採取船を建造する場合， 船主は事前に造船所との間でその積付条件を検討し，積侍量の限界と復原性能との関係を充分に認識して扔く心 きであり，これに基づき船長に対しては運航マニュアルを提供して, 転覆事故の防止に努めるべきであろう。

以上の検討を通して得た知識・経験をもとに，砂利採取船の転覆事故の防止対策として，下記の 5 項目を提案 し，本稿のまとめとしたい。なおこのうちの1 項目でも実行すれば，転覆海難は大幅に減少するのではなかろう 加。

（1）満船にして錯泊する場合，銼地は外力の影響の少ない地点を選定し，錨泊中は当直を必ず立てること。

（2）一定限度以上のビルジ滞留に対する警報装置を設けること。

（3）船倉に砂利の静止角を考慮したトップサイドタンクを設けること。

（4）空倉および船倉内に縦仕切壁を設け，自由水の影響・砂利の移動等を減ずること。

（5）航行区域が平水である砂利採取船に対し, 满載喫水線に淮じた砂利積載量の限界線表示を義務づけるこ と。

本稿をとりまとめるにあたり，終始有益なる助言をいただいた本校船舶工学講座瀬之口宏教授，運用学講座佐 々木茂人教授に対し感謝の意を表する次第です。

\section{参 考 文 献}

（1） 海上保安庁：要救助海難統計，昭和 44 年 48 年

（2）日本造船研究協会：海難船舶の調查および転覆機構の解明に関する研究，昭和 38 年 6 月 